\title{
Surface plasmon resonance imaging of pathogens: the Yersinia pestis paradigm
}

\author{
Hong TT Huynh, Guillaume Gotthard, Jérome Terras, Gérard Aboudharam, Michel Drancourt ${ }^{*}$ \\ and Eric Chabrière
}

\begin{abstract}
Background: Yersinia pestis, causing deadly plague, is classified as a group A bioterrorism bacterium. Some recent DNA-based methods were used for detection of bioterrorism agents.

Results: Y.pestis was used as a model organism to develop an immunosensor based on surface plasmon resonance imaging (SPRi) using monoclonal antibody against Y. pestis F1 antigen. The experimental approach included stepby-step detection of $Y$. pestis membrane proteins, lysed bacteria, intact bacteria, mock-infected powder and mockinfected clinical specimens. SPRi detected on average $10^{6}$ intact Y. pestis organisms in buffer, in mock-infected powder and in a 1:4 mixture with HEL cells.
\end{abstract}

Conclusions: This study offers the proof-of-concept of the SPRi-based detection of a human pathogen in both environmental and clinical specimens.

Keywords: Surface plasmon resonance imaging, Yersinia pestis, Plague, Detection

\section{Background}

Plague is a deadly zoonosis caused by the bacterium Yersinia pestis [1]. It remains a public health problem in many tropical countries including subtropical African countries $[1,2]$ and it is re-emerging in North Africa [3, 4]. There are no longer any plague foci in Europe, though plague had caused devastating epidemics for two millennia [1]. Also, Y. pestis has been classified as a group A bioterrorism agent [5]. Currently, the detection of $Y$. pestis in environmental and clinical specimens, is based on the culture of $Y$. pestis, a process requiring at least $24 \mathrm{~h}$ and a biosafety level 3 laboratory (BSL3) [6]; and PCR-based detection of DNA sequences [7], whose specificity has recently been challenged by the observation of pla sequences, thought to be $Y$. pestis-specific, in other organisms and non-infected rodents [8]. Also, immunochromatography detection of the $Y$. pestis-specific F1 antigen [9-11] is used for research, as this diagnostic assay is not widely available. Recently, some new

\footnotetext{
*Correspondence: michel.drancourt@univ-amu.fr

Faculté de médecine, Unité de Recherche sur les Maladies Infectieuses et Tropicales Emergentes (URMITE), UMR CNRS 7278, IRD 198, INSERM 1095,
} 27, Boulevard Jean Moulin-Cedex 5, Marseille, France approaches such as high-throughput RT-PCR-coupled ESI-MS assay and Luminex were applied to the detection of bioterrorism agents $[12,13]$. These techniques required principally amplified DNA and apparently remained time-consuming.

In this study, $Y$. pestis was used as a model organism to test whether surface plasmon resonance imaging (SPRi) could be used as a novel technique for the rapid detection of pathogens in environmental and clinical specimens. SPRi has advantages (high-throughput, real time, label-free, multi-detection and sensitive) which could be applied to the detection of organisms, such as Y. pestis. Several studies of immune reactions (cells-antibodies, peptides-antibodies) have been conducted with this technique $[14,15]$. Recently, this technique was used to detect the plant pathogenic bacterium Acidovorax avenae subsp. citrulli [16]. However, until now, SPRi has not been used to detect human pathogenic bacteria.

In this study, we challenged the proof-of-concept that SPRi could be used for the rapid detection of highly pathogenic organisms in environmental and clinical specimens, using $Y$. pestis as a model organism. We developed a step-by-step experimental approach to test membrane 
proteins, lysed bacteria, intact bacteria ( $Y$. pestis Orientalis YPA, Medievalis 6B4), mock-infected powder and mock-infected clinical specimens.

\section{Methods}

\section{Materials and instruments}

CS-SPRi Biochips and CS-SPRi Slides covered by a thin layer of gold and functionalized NHS groups were purchased from HORIBA (Palaiseau, France). The ligand used in this study was a mouse monoclonal antibody (mAb) against the F1 antigen of $Y$. pestis [YPF19] $(4.3 \mathrm{mg} / \mathrm{mL})$ purchased from GenWay Biotech, Inc. (Gentaur, Belgium). A mouse non-immune control serum was produced and purified in our laboratory (URMITE, Marseille, France). The protocol to collect serum from non-immune mice has been approved by the French National Ethic Committee for Animals under the reference number 60-12112012. Sodium acetate, ethanolamine and glycine were purchased from Sigma-Aldrich (Saint-Quentin Fallavier, France), while phosphate buffered saline (PBS) was obtained from bioMérieux (La Balme-les-Grottes, France).

\section{Ligand immobilisation}

Ligands diluted in $10 \mathrm{mM}$ sodium acetate, $\mathrm{pH} 5$ at different concentrations (mAb: $1,0.5,0.25 \mathrm{mg} / \mathrm{mL}$; control serum: $1 \mathrm{mg} / \mathrm{mL}$ ) were automatically deposited onto the chip (6 spots for each ligand with a distance of $0.7 \mathrm{~mm}$ between each spot) using a $300 \mathrm{~nm}$ diameter ceramic needle controlled by the mechanical SPRi-Arrayer (HORIBA, Palaiseau, France). Needle rinsing with distilled water for $3 \mathrm{~s}$, followed by drying with compressed air for $3 \mathrm{~s}$, were automatically repeated 3 times both before and after each ligand was deposited. The antibody was immobilised at room temperature in a humid chamber set to $60 \%$ relative humidity. The chip was air-dried and placed in the chip box at $4^{\circ} \mathrm{C}$ until use.

\section{Analyte preparation Membrane proteins}

Suspensions of $Y$. pestis strain YPA (an Orientalis biotype, CSUR P100) in PBS were sonicated 5 times for $1 \mathrm{~min}$ on ice at an amplitude of $30 \mathrm{~W}$ with Q700 Sonicator (Qsonica, LLC, DENTA LABO, Avignon, France). The tubes were centrifuged for $5 \mathrm{~min}$ at $4.000 \times g$. Supernatant was ultra-centrifuged for $1 \mathrm{~h}$ at $100.000 \times g$. The pellet containing membrane proteins was suspended in $500 \mu \mathrm{L}$ PBS or $500 \mu \mathrm{L} 0.2 \%$ Triton X-100, $30 \mathrm{mM}$ Tris $\mathrm{HCl} \mathrm{pH} 8$ and $2 \mathrm{mM} \mathrm{MgCl}_{2}$ and was then left overnight at $4{ }^{\circ} \mathrm{C}$ to solubilize the membrane proteins. Following the same procedure, Escherichia coli was used as a negative control.

\section{Lysed bacteria}

Five hundred $\mu \mathrm{L}$ of various concentrations of $Y$. pestis YPA were broken with acid-washed glass beads in a screw-cap tube using a FastPrep-24 Instrument (MP Biomedicals, Illkirch, France) at a speed $4.0 \mathrm{~m} / \mathrm{V}$ for $40 \mathrm{~s}$. The tube was then centrifuged for $30 \mathrm{~s}$ at $6.700 \times g$ and the supernatant was analysed with SPRi. Bartonella quintana, prepared according to the same protocol, was used as a negative control.

\section{Intact bacteria}

Virulent $Y$. pestis YPA and $Y$. pestis Medievalis 6B4 were cultured on Columbia agar and $5 \%$ sheep blood (bioMérieux) at $32^{\circ} \mathrm{C}, 5 \% \mathrm{CO}_{2}$ for $3-5$ days. E. coli and Staphylococcus aureus used as negative controls were cultured in the same medium at $37^{\circ} \mathrm{C}$. Virulent $Y$. pestis was handled in a BSL3. Bacteria were inactivated with $70 \%$ ethanol. The SPRi specificity test was carried out with $Y$. pestis YPA, Y. pestis Medievalis, E. coli and S. aureus. SPRi sensitivity was tested with different concentrations of $Y$. pestis YPA.

\section{Sandwich test}

A "sandwich" test (mAb/Y. pestis/mAb) was developed on SPRi in order to enhance the sensitivity of the SPRi assay. On a chip with $1 \mathrm{mg} / \mathrm{mL}$ immobilized $\mathrm{mAb}, Y$. pestis YPA $\left(1.2 \times 10^{1}\right.$ to $\left.1.2 \times 10^{7} \mathrm{CFU} / \mathrm{mL}\right)$ was tested within $10 \mathrm{~min}$, followed by an injection of $\mathrm{mAb}$ of $1 / 500$. The area under the curve for each injection was analysed using GraphPad PRISM V6 software (GraphPad Software, Inc., USA). The first phase (bacterial injection) from 0 to $11.5 \mathrm{~min}$, the second phase (antibody injection) from 11.5 to $22 \mathrm{~min}$ and the entire process from 0 to $22 \mathrm{~min}$ were analysed.

\section{Mock-infected powder}

$Y$. pestis YPA mixed at different concentrations $\left(10^{8}, 10^{6}\right.$, $10^{4} \mathrm{CFU} / \mathrm{mL}$ ) with flour powder was tested on SPRi to estimate whether this technique could detect the pathogen in environmental samples in mimicking a bioterrorist alert. Powder mixed with either PBS or E. coli were used as negative controls. The experiment was repeated three times.

\section{Mock-infected clinical specimens}

$Y$. pestis YPA mixed with HEL cells at ratio 1:1, 1:10, $1: 100$ was used as a model to evaluate the capability of SPRi to detect the pathogen in infected clinical specimens. A suspension of non-infected HEL cells was used as negative control. This experiment was performed in triplicate. 


\section{SPRi experiments}

The experiments were conducted using the SPRi-Plex II system and monitored using SPRi P5.0.2-View software (HORIBA, Palaiseau, France). The running buffer for the SPRi-Plex II system was $10 \mathrm{mM}$ PBS. Initial buffer flow rate was $500-1,000 \mu \mathrm{L} / \mathrm{min}$ to fill the fluid system for $15 \mathrm{~min}$. Once the chip was inserted into the machine, the analysis cell was filled at a flow rate of $750-1,000 \mu \mathrm{L} / \mathrm{min}$, followed by a flow rate of $50 \mu \mathrm{L} / \mathrm{min}$ and a temperature of $37^{\circ} \mathrm{C}$ was used for all experiments. After system stabilization, plasmon images were acquired by software and system mirror and camera. The study area deposits were detected on the previously acquired high-contrast image and spot and spot family definitions were performed. The plasmon curve and resonance angle were determined for each spot. The mirror system was shifted by the resonance angle and the experiments were conducted with this value.

The surface of the chip was saturated for $10 \mathrm{~min}$ with $500 \mu \mathrm{L}$ of $1 \mathrm{M}$ ethanolamine $\mathrm{pH} 9$ and regenerated for 10 min with $500 \mu \mathrm{L}$ of $10 \mathrm{mM}$ glycine $\mathrm{pH} 1.85$ to remove any non-covalent bindings (unfixed antibodies and ethanolamine). The system was calibrated by comparing the reflectivity of $12.5 \mathrm{mM}$ PBS and of $10 \mathrm{mM}$ PBS buffer. Control serum not targeting $Y$. pestis was defined as a reference surface. This was used to make subtracted curves of each spot family in real time to eliminate non-specific signals. A $400 \mu \mathrm{L}$-volume of each sample was loaded into the system $(200 \mu \mathrm{L}$ for analysis, $200 \mu \mathrm{L}$ for the carrier fluid). The interaction of each sample with the surface of the chip was measured for $10 \mathrm{~min}$. Changes in reflectivity were monitored in real time on the graph and on the chip image. After each experiment, the chip was regenerated with $10 \mathrm{mM}$ glycine $\mathrm{pH} 1.85$.

\section{Data analyses}

The data were analysed using SPRi-Analysis software V1.2. The reflectivity change subtracted from the negative control plus two standard deviations was considered as positive. The data were analysed by means of a t-test in GraphPad PRISM V6 for p value (GraphPad Software, Inc., USA).

\section{Results}

\section{Tests with membrane proteins}

In the first series of SPRi experiments, we tested the membrane proteins of $Y$. pestis YPA and E. coli (negative control) solubilized in PBS and in Triton X-100. As expected, in all cases the membrane proteins of E. coli gave the same signals as the blank (Figure 1). The membrane proteins of $Y$. pestis YPA solubilized in PBS $(0.336 \mathrm{mg} / \mathrm{mL})$ and in Triton $\mathrm{X}-100(0.361 \mathrm{mg} / \mathrm{mL})$ gave statistically different signals to that of $E$. coli solubilized in PBS $(0.174 \mathrm{mg} / \mathrm{mL})$ and in Triton X-100 (0.168 mg/ $\mathrm{mL})(\mathrm{p}<0.05)$. The detection signals of $Y$. pestis proteins solubilized in Triton X-100 was higher than in PBS ( $\mathrm{p}<0.05)$. Indeed, SPRi was able to detect $Y$. pestis membrane proteins extracted with PBS and even more so with Triton X-100.

\section{Sensitivity with lysed and intact bacteria}

SPRi experiments were conducted with decreasing concentrations of lysed $Y$. pestis and lysed B. quintana used as negative control according to the FastPrep protocol to test detection sensitivity of lysed bacteria. Figure 2 shows that, as expected, the negative control remained negative. SPRi was able to give statistically different signals up to $6.4 \times 10^{6} \mathrm{CFU} / \mathrm{mL}$ lysed $Y$. pestis compared to the negative control $(\mathrm{p}<0.05)$. The same experiment performed with intact bacteria gave the same detection threshold $\left(6.4 .10^{6} \mathrm{CFU} / \mathrm{mL}\right)$. Figure 2 also shows that the signals with lysed bacteria were statistically less significant than intact bacteria, whatever the concentration $(\mathrm{p}<0.05)$.

\section{Specificity and effect of mAb concentration}

In this step, we wanted to test the specificity of this technique. Four different kinds of intact bacteria (E. coli, $S$. aureus, $Y$. pestis YPA and $Y$. pestis 6B4) were tested with anti- $Y$. pestis mAb previously immobilized on a chip at $1,0.5$ and $0.25 \mathrm{mg} / \mathrm{mL}$. In Figure 3, E. coli and S. aureus did not show any significant interaction with anti- $Y$. pestis mAb, as expected. $Y$. pestis YPA and $Y$. pestis $6 \mathrm{~B} 4$ gave significantly different signals with $\mathrm{mAb}$, whatever the mAb concentration, compared E. coli, S. aureus $(\mathrm{p}<0.05)$. Moreover, we noted that interaction between $\mathrm{mAb}$ and $Y$. pestis correlated with mAb concentration. $\mathrm{mAb}$ at $1 \mathrm{mg} / \mathrm{mL}$ gave statistically significant signals compared to $0.5 \mathrm{mg} / \mathrm{mL}$ and $0.25 \mathrm{mg} / \mathrm{mL}$ in the test with the same concentration of $Y$. pestis $(\mathrm{p}<0.05)$.

\section{Sandwich test}

In an effort to improve the sensitivity of SPRi in detection of bacteria, we applied a sandwich technique (mAb/Y. pestis/mAb). The sandwich test signals were significantly higher than those obtained following non-specific binding of the injection of control (PBS and monoclonal antibody). In Figure 4a, the analysis of the area under the curve showed that the sandwich test could improve the sensitivity of SPRi. In Figure $4 \mathrm{~b}$, by testing decreasing concentrations of bacteria $\left(1.2 \times 10^{7}\right.$ to $1.2 \times 10^{1} \mathrm{CFU} /$ $\mathrm{mL}$ ) using the sandwich technique, SPRi was able to detect $Y$. pestis YPA up to $1.2 \times 10^{6} \mathrm{CFU} / \mathrm{mL}(\mathrm{p}<0.05)$.

\section{Mock-infected powder and clinical specimens}

To evaluate the ability to detect pathogen in environmental and clinical specimens, we tested $Y$. pestis mixed with 


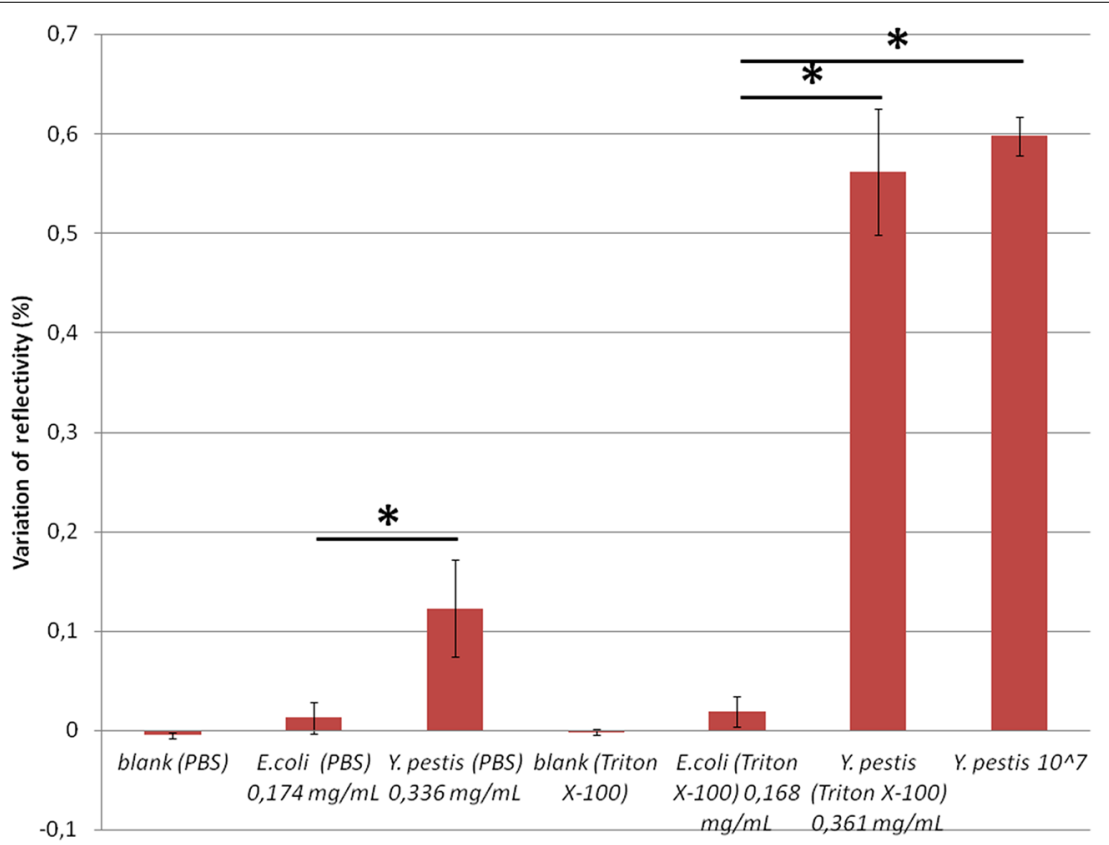

Figure 1 Test of membrane proteins with SPRi. Membrane proteins of E. coli (negative control) and Y.pestis solubilized in PBS and in Triton X-100 were tested. $\mathrm{mAb}$ concentration was $1 \mathrm{mg} / \mathrm{mL}$. Asterisk represents a statistically significant difference with E. coli solubilized in PBS and in Triton $\mathrm{X}-100$.

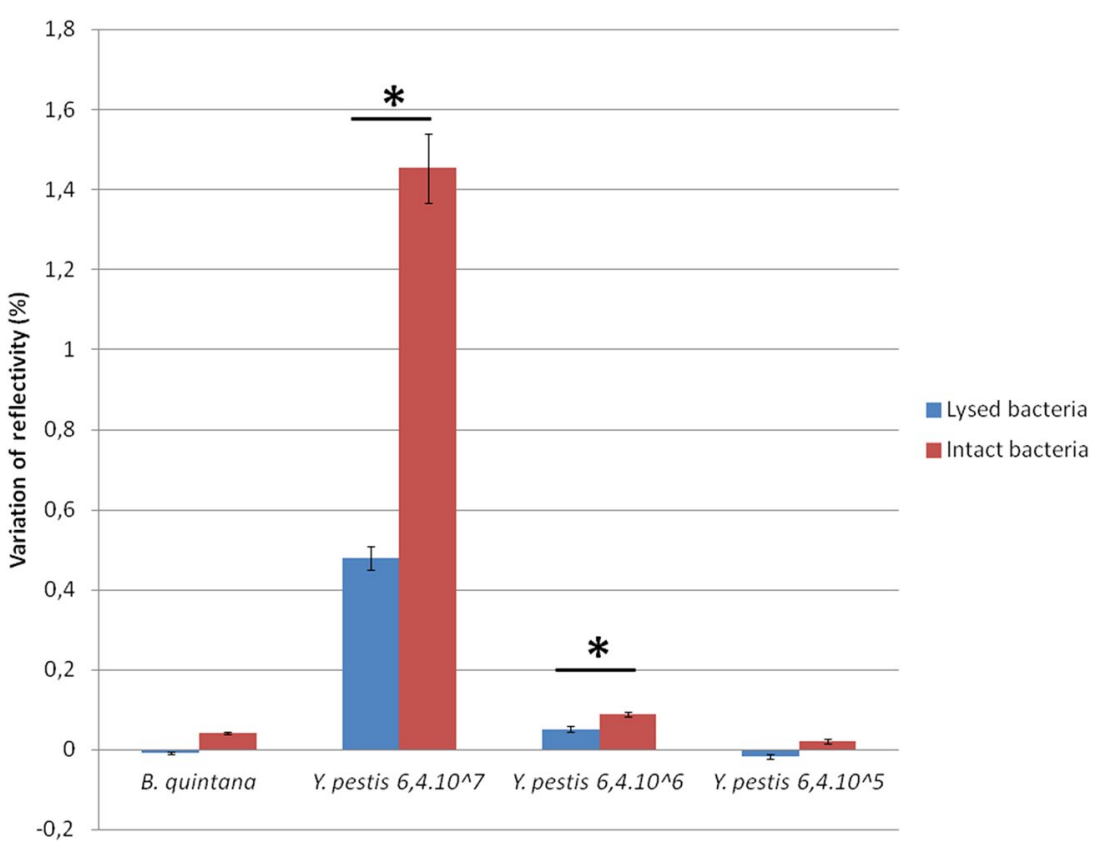

Figure 2 Comparison of the sensitivity of SPRi in detection of lysed bacteria (FastPrep) and intact bacteria. The signals with lysed bacteria were less statistically significant than intact bacteria, whatever the concentration. mAb concentration was $1 \mathrm{mg} / \mathrm{mL}$. Asterisk represents a statistically significant difference between lysed and intact bacteria.

powder and HEL cells. Figure 5 shows that mixtures of Y. pestis YPA at $10^{8}$ and $10^{6} \mathrm{CFU} / \mathrm{mL}$ with powder gave statistically significant signals compared to the negative controls (PBS or E. coli with powder) (p < 0.05). In Figure 6, Y. pestis YPA $\left(10^{6} \mathrm{CFU} / \mathrm{mL}\right)$ could be detected in a mixture with HEL cells at a cell number ratio of 1:1, 


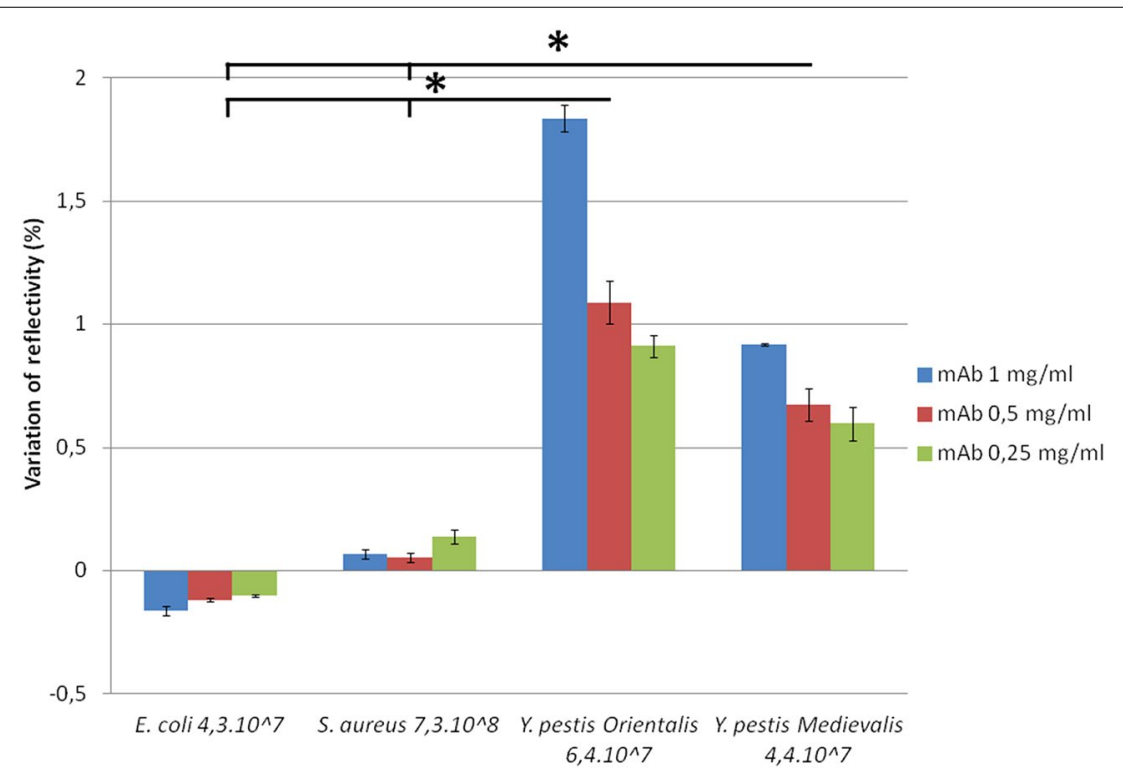

Figure 3 Specificity tests of SPRi with intact bacteria. Asterisk represents a statistically significant difference with E. coli and S. aureus.

corresponding to a mass ratio of $1: 4(\mathrm{p}<0.05)$. In this experiment, the protein concentrations of $Y$. pestis YPA and HEL were 0.61 and $2.3 \mathrm{mg} / \mathrm{mL}$, respectively. The other mixtures did not give statistically significant differences in refractive index by comparison with the negative control (non-infected cells). Here, a mixture of $10^{6} \mathrm{CFU} /$ $\mathrm{mL}$ of $Y$. pestis with powder or with HEL cells could be also detected with SPRi.

\section{Discussion}

Rapid and accurate detection of harmful organisms in both clinical and environmental specimens is a constant goal to serve medical diagnosis and protection. SPRi, being reported as a high-throughput method for the detection of molecule interactions, including antigenantibody interactions, held promise to help in the rapid detection of organisms. The results reported in the present study were validated by numerous controls, indicating that SPRi yielded the specific detection of $Y$. pestis used as a model organism.

As SPRi-based measures incorporate no-labelled Mab and since all substances could affect the reflectivity index of the solution, it was important to distinguish specific interactions from non-specific ones. To eliminate nonspecific binding to antibodies immobilized on the chip, the antibody not targeting the bacteria could be used as a blank [17]. We used the non-immune purified serum as a reference surface and the injection of other bacteria as negative controls. Reference surface interactions were automatically subtracted and results compared with the negative control to identify the specific interactions.
Moreover, specificity was confirmed by the observation that Gram-negative (E. coli, B. quintana) and Gram-positive (S. aureus) bacteria did not give any signal with anti$Y$. pestis $\mathrm{mAb}$. Moreover, signal intensity increased with antibody concentration, as has previously been reported [16]. Here, $6.4 \cdot 10^{6} / \mathrm{mL}$ lysed or intact bacteria alone or in mock-infected powder and clinical specimens could be detected by SPRi. SPRi was significantly less sensitive when lysed bacteria were used rather than intact bacteria, by contrast with a previous observation involving $A$. avenae subsp. citrulli [16]. The sandwich assay, however, was able to $2.4 \cdot 10^{5} Y$. pestis bacteria, in line with a previous study by Puttharugsa et al. [16].

Altogether, SPRi was able to detect $10^{5} \mathrm{Y}$. pestis bacteria, an inoculum in the range of that expected to cause deadly plague after natural or criminal exposure to the pathogen. Indeed, the lowest inoculum of $Y$. pestis that consistently gave a $100 \%$ mortality rate in a mouse model was $10^{4} \mathrm{CFU}$ [18], suggesting that an inoculum of bacteria found in a bioterrorism attack would be $>10^{4} \mathrm{CFU}$. Specimen incubation for a few hours prior to the SPRi assay is a promising way to further improve sensitivity, as previously reported for E. coli O157:H7 [19]. Some new approaches were applied in the detection of bioterrorism agents. These techniques were principally based on amplified DNA-sequence detection including high-throughput RT-PCR-coupled ESIMS assay and Luminex assay [12, 13]. According to the current state of the art, SPRi is less sensitive than PCR-based techniques [20] and this sensitivity remains to be improved. Improving SPRi sensitivity is warranted 

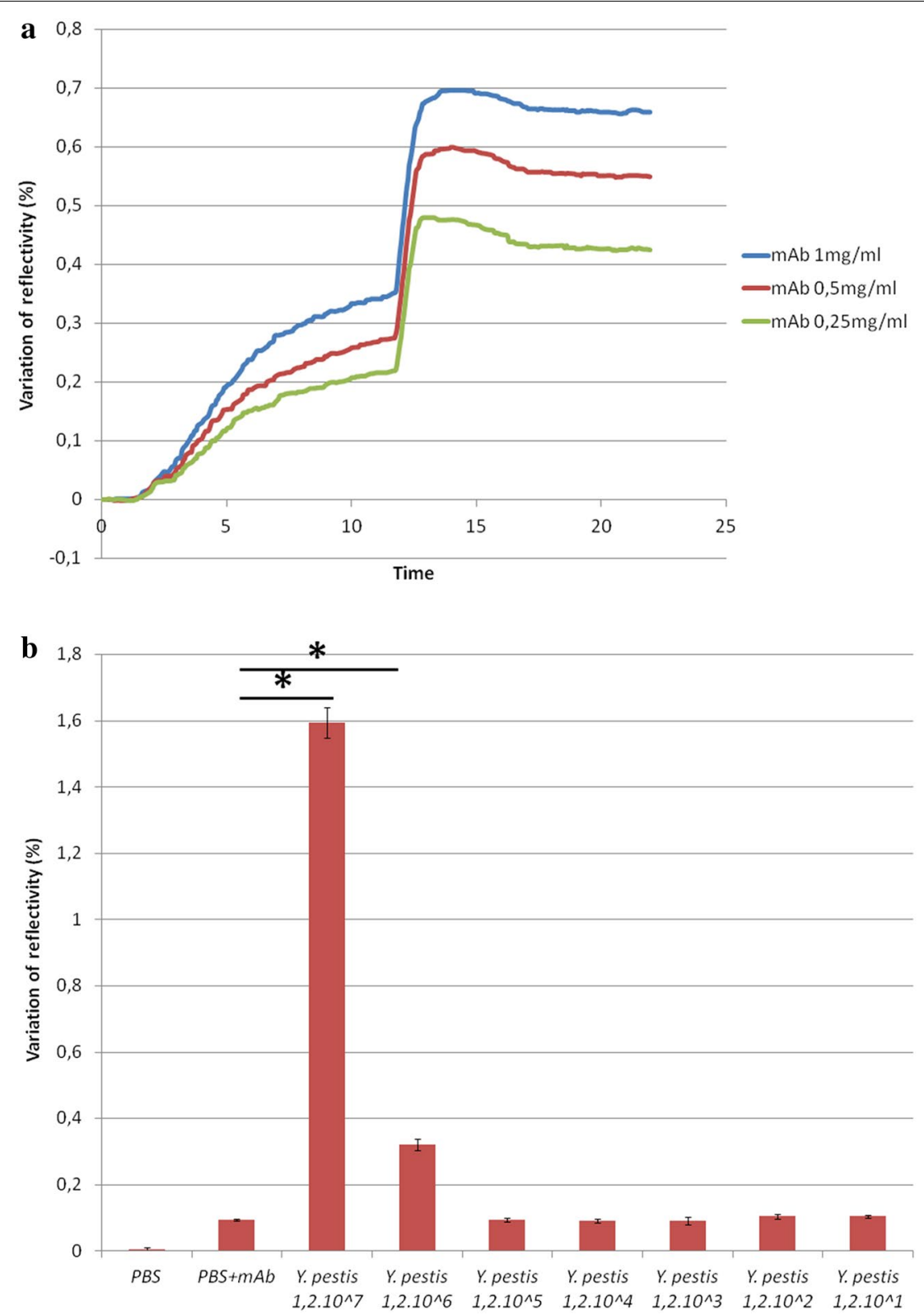

Figure 4 a Area under the reflectivity curve. The second phase area (injection of mAb, 12-22 min) was 4 times greater than the first phase (injection of bacteria, the conventional technique, $0-12 \mathrm{~min}$ ), respectively. $\mathbf{b}$ Sandwich tests ( $\mathrm{mAb}+$ bacteria $+\mathrm{mAb}$ ). Decreasing concentrations of Y. pestis (CFU/mL) were tested by the sandwich technique, $\mathrm{PBS}+\mathrm{mAb}$ was used as negative control. $\mathrm{mAb}$ concentration was $1 \mathrm{mg} / \mathrm{mL}$. Asterisk represents a statistically significant difference with PBS + mAb.

as SPRi has advantages over PCR-based techniques: SPRi is specific whereas it has been shown that pla, a long-standing target for the PCR-based detection of $Y$. pestis is in fact detectable in non-Yersinia organisms, including the host [8]. In particular, Y. pestis is easily engineered to intentionally modify PCR targets, thus helping the pathogen and bioterrorism agent escape detection. Also, SPRi is not too time-consuming, requiring only $40 \mathrm{~min}$ for a direct assay $(20 \mathrm{~min}$ for infection of analyte, $20 \mathrm{~min}$ for negative control) and $1 \mathrm{~h}$ for a sandwich assay. A chip with many kinds of mAb could be used to detect different organisms. Moreover, this chip could be reused several times. This makes SPRi appropriate for rapid, cheap, multiplexed detection. Once sensitivity is improved, this technique would be perfectly suitable for sample analysis in the context of a bioterrorism emergency or for routine analysis in an epidemic area. 


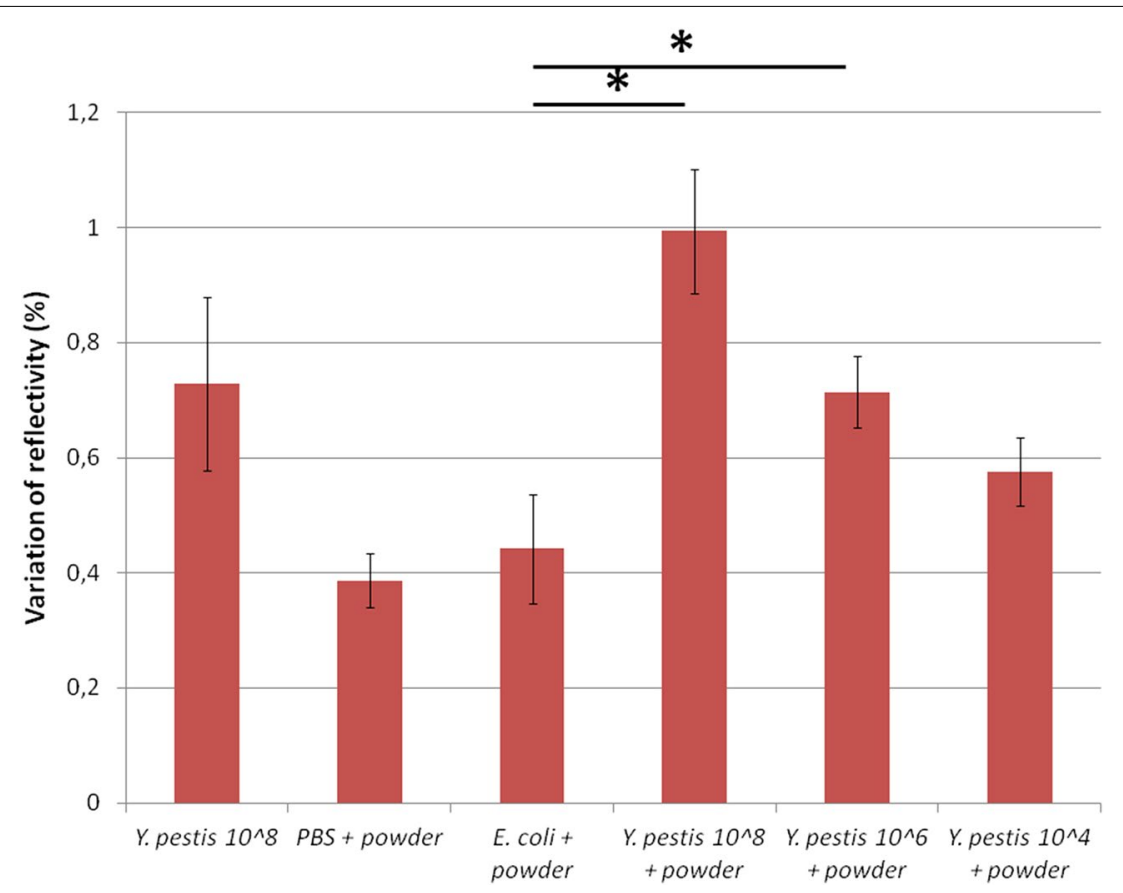

Figure 5 Test of mock-infected powder with SPRi. mAb concentration was $1 \mathrm{mg} / \mathrm{mL}$. Asterisk represents a statistically significant difference with $E$. coli + powder.

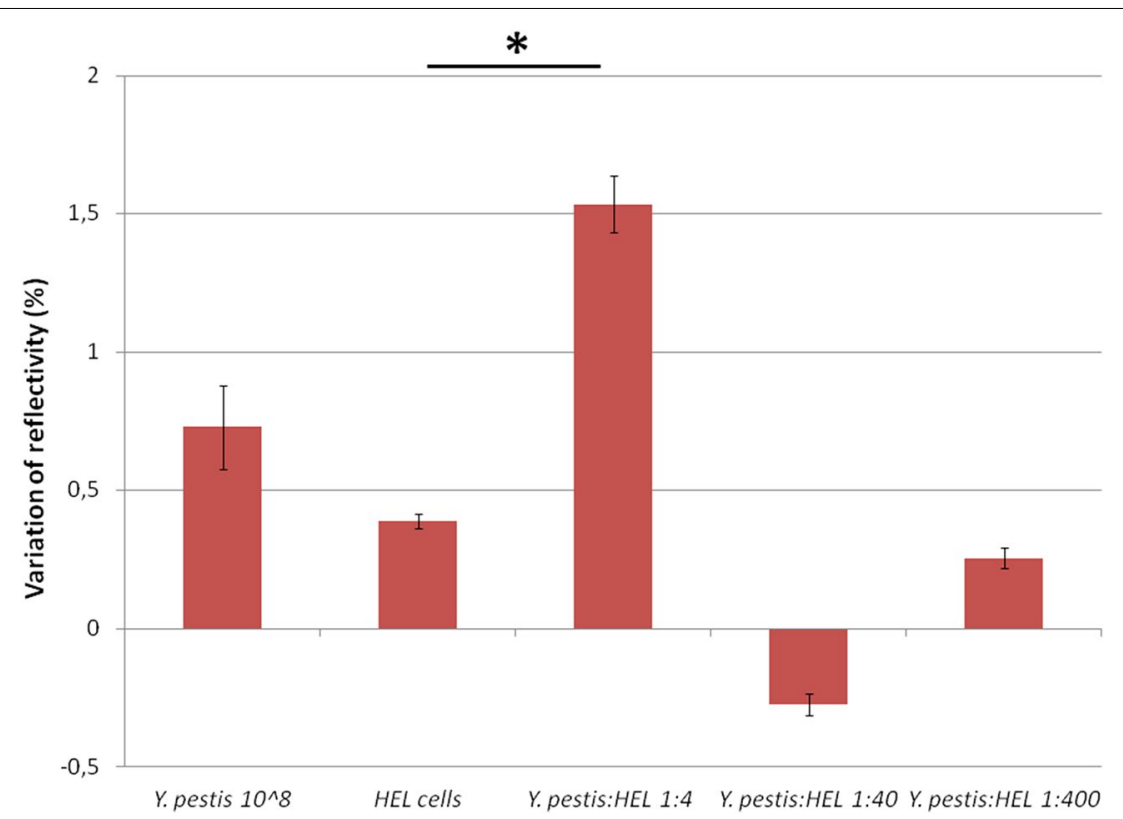

Figure 6 Test of mock-infected clinical specimens with SPRi. mAb concentration was $1 \mathrm{mg} / \mathrm{mL}$. Asterisk represents a statistically significant difference with HEL cells.

\section{Conclusions}

In conclusion, SPRi is a new technique for the rapid detection of bacteria in environmental and clinical specimens, as illustrated here using $Y$. pestis as a model organism. Future improvements will be directed towards increasing the sensitivity of the technique. 


\section{Abbreviations}

SPRi: surface plasmon resonance imaging; $\mathrm{mAb}$ : monoclonal antibody; PBS: phosphate buffered saline; CFU: colony-forming unit; HEL: human embryonic lung cells; BSL3: biosafety level 3 laboratory; PCR: polymerase chain reaction.

\section{Authors' contributions}

HTTH, GG, JT, GA, MD and EC: (1) have made substantial contributions to conception and design, or acquisition of data, or analysis and interpretation of data; (2) have been involved in drafting the manuscript or revising it critically for important intellectual content; (3) have given final approval of the version to be published; (4) agree to be accountable for all aspects of the work in ensuring that questions related to the accuracy or integrity of any part of the work are appropriately investigated and resolved. All authors read and approved the final manuscript.

\section{Acknowledgements}

This work was supported by “Unité de Recherche sur les Maladies Infectieuses et Tropicales Emergentes", Marseille, France.

\section{Compliance with ethical guidelines}

\section{Competing interests}

The authors declare that they have no competing interests.

Received: 4 September 2014 Accepted: 17 June 2015

Published online: 24 June 2015

\section{References}

1. Raoult D, Mouffok N, Bitam I, Piarroux R, Drancourt M (2013) Plague: history and contemporary analysis. J Infect 66:18-26

2. Neerinckx SB, Peterson AT, Gulinck H, Deckers J, Leirs H (2008) Geographic distribution and ecological niche of plague in sub-Saharan Africa. Int J Health Geogr 7:54

3. Bertherat E, Bekhoucha S, Chougrani S, Razik F, Duchemin JB, Houti L et al (2007) Plague reappearance in Algeria after 50 years, 2003. Emerg Infect Dis 13:1459-1462

4. Bitam I, Ayyadurai S, Kernif T, Chetta M, Boulaghman N, Raoult D et al (2010) New rural focus of plague, Algeria. Emerg Infect Dis 16:1639-1640

5. Riedel S (2004) Biological warfare and bioterrorism: a historical review. Proc (Bayl Univ Med Cent) 17:400-406

6. Bearden SW, Perry RD (2008) Laboratory maintenance and characterization of Yersinia pestis. In: Current protocols in microbiology. Chapter 5. Wiley, New York

7. Drancourt M, Aboudharam G, Signoli M, Dutour O, Raoult D (1998) Detection of 400-year-old Yersinia pestis DNA in human dental pulp: an approach to the diagnosis of ancient septicemia. Proc Natl Acad Sci USA 95:12637-12640
8. Janse I, Hamidjaja RA, Reusken C (2013) Yersinia pestis plasminogen activator gene homolog in rat tissues. Emerg Infect Dis 19:342-344

9. Bianucci R, Rahalison L, Massa ER, Peluso A, Ferroglio E, Signoli M (2008) Technical note: a rapid diagnostic test detects plague in ancient human remains: an example of the interaction between archeological and biological approaches (southeastern France, 16th-18th centuries). Am J Phys Anthropol 136:361-367

10. Chanteau S, Rahalison L, Ralafiarisoa L, Foulon J, Ratsitorahina M, Ratsifasoamanana L et al (2003) Development and testing of a rapid diagnostic test for bubonic and pneumonic plague. Lancet 361:211-216

11. Rajerison M, Dartevelle S, Ralafiarisoa LA, Bitam I, Dinh TN, Andrianaivoarimanana V et al (2009) Development and evaluation of two simple, rapid immunochromatographic tests for the detection of Yersinia pestis antibodies in humans and reservoirs. PLoS Negl Trop Dis 3:e421

12. Jeng K, Hardick J, Rothman R, Yang S, Won H, Peterson S et al (2013) Reverse transcription-PCR-electrospray ionization mass spectrometry for rapid detection of biothreat and common respiratory pathogens. J Clin Microbiol 51:3300-3307

13. Schweighardt AJ, Battaglia A, Wallace MM (2014) Detection of anthrax and other pathogens using a unique liquid array technology. J Forensic Sci 59:15-33

14. Kato K, Ishimuro T, Arima Y, Hirata I, Iwata H (2007) High-throughput immunophenotyping by surface plasmon resonance imaging. Anal Chem 79:8616-8623

15. Cherif B, Roget A, Villiers CL, Calemczuk R, Leroy V, Marche PN et al (2006) Clinically related protein-peptide interactions monitored in real time on novel peptide chips by surface plasmon resonance imaging. Clin Chem 52:255-262

16. Puttharugsa C, Wangkam T, Huangkamhang N, Gajanandana O, Himananto O, Sutapun B et al (2011) Development of surface plasmon resonance imaging for detection of Acidovorax avenae subsp. citrulli (Aac) using specific monoclonal antibody. Biosens Bioelectron 26:2341-2346

17. Gutierrez-Gallego R, Bosch J, Such-Sanmartin G, Segura J (2009) Surface plasmon resonance immuno assays - a perspective. Growth Horm IGF Res 19:388-398

18. Lathem WW, Crosby SD, Miller VL, Goldman WE (2005) Progression of primary pneumonic plague: a mouse model of infection, pathology, and bacterial transcriptional activity. Proc Natl Acad Sci USA 102:17786-17791

19. Mondani L, Roupioz Y, Delannoy S, Fach P, Livache T (2014) Simultaneous enrichment and optical detection of low levels of stressed Escherichia coli 0157:H7 in food matrices. J Appl Microbiol 117:537-546

20. Malou N, Tran TN, Nappez C, Signoli M, Le Forestier C, Castex D et al (2012) Immuno-PCR - a new tool for paleomicrobiology: the plague paradigm. PLoS One 7:e31744

\section{Submit your next manuscript to BioMed Central and take full advantage of:}

- Convenient online submission

- Thorough peer review

- No space constraints or color figure charges

- Immediate publication on acceptance

- Inclusion in PubMed, CAS, Scopus and Google Scholar

- Research which is freely available for redistribution

Submit your manuscript at 